\title{
População Brasileira, Uma análise da distrıbuição de seus grupos profissionais (*)
}

$312.93(81)$

Dulcy Melgaço Filgueiras

\section{INTRODUÇÃO}

A ntes de se iniciar um estudo da estrutura da população ativa brasileira, torna-se necessário reproduzirem-se aqui alguns conceitos bem como algumas palavras sôbre a evolução econômica de nosso país que permitam a compreensão dos fenômenos populacionais ocorridos no passado e observados ainda nos últimos anos.

\section{POPULAÇÃO}

\section{Conceito}

A palavra população, do latim populatio, significava curiosamente devastação, «ravage, tout comme depopulatieon». (1)

A simples possibilidade de flutuações da população indica que o sentido originário da palavra, que era o de despovoamento, não estaria longe de corresponder ao seu sentido atual; bastaria para isso que tomássemos como ponto de partida, ao estudar-se a população, o conceito de despovoamento. Assim, a população de um território seria uma resultante de um maior ou menor despovoamento. Quando a taxa de natalidade fôsse superior à de mortalidade haveria então o povoamento (aumento de população).

Êsse despovoamento ou povoamento pode ser determinado por dois motivos principais: a predominância de uma ou outra das taxas acima referidas -- que provocariam as diminuições ou os aumentos naturais - e as migrações. Estas últimas são particularmente interessantes pois determinam o despovoamento de uma região em benefício de outras.

Generalizando, podemos dizer que, dentro de uma estrutura social, pode haver despovoamento de uma classe ou grupos, em benefício de outras, isto é, a passagem de indivíduos de determinados grupos para outros. Êste tipo de passagem constitui um dos aspectos da mobilidade social, fenômeno que apresenta grande interêsse para os estudos econômicos da população.

1. (*) Trabalho apresentado ao Curso Elementos de Economia, ministrado pelo Serviço de Aperfeiçoamento da Prefeitura do Distrito Federal.

(1) Landry, Adolphe, Traité de Demographie, Payot, Paris, p. 7. 


\section{Mobilidade Social}

Constitui a mobilidade social a movimentação de indivíduos ou grupos de uma posição social para outra e a circulação dos motivos, valores e características culturais entre indivíduos e grupos. A mobilidade pode ser horizontal ou vertical.

Interesșa-nos particularmente neste trabalho a movimentação de individuos ou grupos. Ocorre a mobilidade horizontal quando a transição do individuo ou do grupo se opera dentro do mesmo stratum social; nela se incluem as migrações.

A mobilidade vertical - passagem de um indivíduo ou grupos de um stratum social para outro - pode ser ascendente ou descendente.

Pode verificar-se em todos os diversos planos sociais - o econômico, quando o cidadão passa da classe pobre para a rica, ou vice-versa; o ocupar cional, quando o movimento é de baixo para o alto stratum ocupacional (ascendente) ou vice-versa.

O processo de mobilidade vertical exerce uma série de influências importantes sôbre a vida social, não só selecionando a população de vários strata, como também englobando os descendentes das classes mais altas e mais baixas. Assim, cm dado momento, a população de qualquer classe social se compõe de pessoas recrutadas das diversas ocupações. Obtém-se a distribuição mais eficiente entre as várias posições, se todos são recompensados de acôrdo com o talento. A mobilidade torna a estrutura social elástica, elimina as classes sociais e o seu isolacionismo enfraquece o tradicionalismo e estimula o racionalismo.

Suas influências, diretas e indiretas, em todos os aspectos da organização social, são fortes e complexas. (2) A manutenção de um alto grau de mobilidade social constitui condição do rápido crescimento econômico.

\section{Mobilidade de trabalho}

Mais modernamente, a palavra inglêsa mobility é muito usada, especialmente para designar os movimentos de operários. A expressão mobilidade de trabalho (mobility of work) encontra-se freqüentemente e corresponde a uma noção precisa. (3) Noutros autores britânicos, o têrmo mobility of work tem u'a amplitude maior do que em francês, pois designa:

a) a mobilidade de região a região;

b) a mobilidade de profissão a profissão;

c) as variações na repartição geral da população entre as profissões, variações devidas não apenas às variações nas trocas de profissões existentes, mas também às alterações de orientação que ocorrem desde que novas gerações tomem o lugar das que se vão. (4)

(2) Sorokin, Pitirim A., Social Mobility New York, 1927, in Encyclopædia of the Social Sciences, New York, Macmillan Company, MCMXXXV, p. 554.

(3) Jaccard, Madeleine, La Mobilité de la Main d'œuvte, Librairie de l'Université, F. Rouge \& Cie., S.A., Lausanne, p. 23.

(4) Ob. cit., pp. 23-24. 
Êsses três tipos de mobilidade de trabalho ocorrem todos no Brasil, onde diversos fatôres os estimulam.

\section{A População e as Condições Econômicas}

Por diversos modos as condições econômicas contribuem para alterar a evolução demográfica de um país.

As coletividades humanas se deixam alterar pelas taxas de natalidade, mortalidade e pelas migrações que, por sua vez, são influenciadas, direta e indiretamente, pelos fatôres econômicos - pela economia do país.

O ponto a se discutir é como se adaptam, uma à outra, economia e população: Sugere PiERre Fromont duas soluções lògicamente possíveis. (5)

«- ou bem a população se adapta aos recursos econômicos aumentando ou diminuindo até que êles se desenvolvam ou se reduzam. O volume da população aparecerá como sendo determinado pela atividade econômica, como uma conseqüência dos fenômenos econômicos;

- ou bem o equilibrio se estabelecerá, de maneira inversa são os recursos que se adaptam às populações. Desde que estas aumentem, os recursos econômicos se ampliarão e, inversamente, a uma população crescente corresponderá uma economia em declinio. É a população que determinará a vida econômica; ela aparecerá como uma causa dos fenômenos econômicos;

- Essas duas categorias de equilibrio não se excluem de maneira alguma; podem coexistir; a reação do efeito sôbre a causa é um fenômeno muitas vêzes observado e isolado pela análise».

Conclui Roberto Simonsen. (6)

«Do harmonioso equilibrio entre o homem, o ambiente e os recursos econômicos resultará o bem-estar de uma população».

\section{POPULAÇão ATIVA E POPULAÇÃo ECONÔMICAMENTE ATIVA Conceito. Distinção}

Segundo os técnicos da Repartição Internacional do Trabalho (O.I.T.): (7)

«A noção fundamental de população «ativa ou trabalhadora» é quase universalmente a mesma. Representa em geral, por definição, a parte da população que fornece a mão-de-obra para a produção dos bens e dos serviços. Além dos assalariados e dos empregadores, das pessoas que trabalham por conta própria e dos membros ativos não remunerados de uma familia, abrange tambér tanto os desempregados, como as pessoas que efetivamente traba. lham por ocasião do censo.» ( $\mathrm{O}$ grifo é nosso)

(5) Fromont, Pierre - Demographie Economique, Les Rapports de l'Economie el de la Population dans le Monde, Payot, Paris, 1942, p. 21.

(6) Simonsen, Roberto C., Recursos Econômicos e Movimento das Populações,, Re vista Brasileira de Estatistica, abril-junho, 1940, Ano I, n. 2, p. 199. 
No entanto, ao estabelecer os dois critérios básicos utilizados para identificar os membros de uma população ativa: «o do trabalhador remunerado» e o da «mão-de-obra», ao que parece, não incluem aquêles técnicos os membros ativos não remunerados de uma família. Isto porque, definem o trabalhador remunerado como

«a pessoa que, habitualmente ou em grande parte do tempo, exerce uma profissão que lhe permite ganhar dinheiro (ou o equivalente de uma soma de dinheiro) ou ainda na qual colabore para a produção de mercadorias destinadas ao mercado». (8)

e consideram como participante de mão-de-obra

«tôdas as pessoas que têm um emprêgo ou estão à procura de um emprêgo durante um curto período especificado, geralmente uma semana ou um dia». (9) Ambos os critérios excluem os membros aivos não remunerados de uma família.

Isto nos faz crer que, ao fixar os dois critérios acima aludidos, já estavam cogitando da população econômicamente ativa.

De acôrdo com o professor Mortara (10) porém,

«nenhum economista concordaria em excluir da população econômicamente ativa as mulheres que trabalham exclusivamente no lar e para o lar, sem remuneraçâ exercendo atividades essenciais para a vida familiar e social. Cumpre, todavia, observar - para desculpa do Serviço Nacional de Recenseamento de 1940 - que êsse critério de exclusão prevaleceu e ainda prevalece nos meios estatísticos internacionais, confundindo-se o conceito geral de "atividade econômica», o qual abrange tôdas as formas de ação que visam à satisfação das necessidades humanas, ora com o conceito de "atividade extradoméstica», ora com o de "atividade exercida com objetivo de lucro», ora com o de «atividade remunerada em moeda», etc.: formas tôdas, que é conveniente discriminar, sem entretanto se lhes atribuir o monopólio do caráter de atividades econômicas. Em conseqüência da aplicação dêsse critério errado, infelizmente estendida ao censo demográfico de 1950, qualifica-se como «econômicamente ativa» no sentido convencional apenas uma parte da população que é tal segundo a significação científica da expressão».

(7) A População Ativa no Mundo, in Revista Brasileira de Estatistica, Ano XVII, outubro-dezembro, 1956, n. ${ }^{\circ} 68$, p. 287.

(8) Ob. cit., p. 287.

(9) Ob. cit., p. 287.

(10) Mortara, Giorgio - As atividades da Bahia, segundo os Censos Demográficos de 1940 e 1950, in Análises Criticas de Resultados dos Censos Demográficos, I.B.G.E., Conselho Nacional de Estatistica, 1956, p. 108-109. 
Assim sendo as referências neste trabalho a população ativa excluem aquela parte que se dedica às atividades domésticas não remuneradas; embora estas figurem em algumas tabelas anexas a êste trabalho, para fins comparativos.

\section{Significado Econômico da Distribuição da População Ativa}

Foi a partir de 1798, quando Malthus publicou seu Essay on Population, que o aumento de população começou a constituir objeto de preocupação e estudos. Temia-se que a terra se tornasse escassa em relação ao volume de população e a humanidade fôsse levada à fome. A teoria Malthusiana, porém, só apresenta ainda certa validade nos países essencialmente agrícolas. É que a divisão do trabalho - característica da sociedade moderna -.- e especialização dela decorrente vieram dar feição inteiramente diferente ao problema. Se a populaçãc aumenta, a tendência é aumentar o número de operários - fato: trabalho ... e a solução adequada será o seu aproveitamento eficiente, através de uma distrihuição racional que leve a colocar cada operário na função para a qual está mais treinado - especializado e onde apresentará maior rendimento. A preocupaçäo passou a ser, não só a melhor distribuição dêsses operários tendo em vista sua capacidade, bem assim sua colocação naquelas atividades que produzam os bens de que depende a manutenção do ritmo do sistema econômico, pois

«se o acréscimo do fator trabalho (população) não fôr acompanhado do fator capital, é provável que o crescimento da população seja seguido de uma redução da produtividade média.»(11) dificil:

Quanto aos paises econômicamente subdesenvolvidos ficam em situação

«de um lado sua pressão demográfica impede-os de formar capitais, na medida das necessidades de suas populações; de outro; êsses poucos capitais naturalmente reduzem o ritmo de sua formação, acrescendo que parte dêsse já de si deficiente capital, é devorada pela grande mortalidade juvenil, cujo máximo vai de 0 a 10 anos». (12)

A formação dêsses capitais fica na dependência do volume da população e, sobretudo, da maneira de distribuição da população trabalhadora. A maneira de se aumentar êsse capital é distribuindo-se essa população trabalhadora por aquelas atividades que promovem o aumento dos bens de conisumo de uso único; uma vez que não se pode aumentar a terra embora se possa fecundá-la, grande parte da população ativa deverá estar empenhada na manufatura dos instrumentos da produção.

A tarefa de bem distribuir a população não é, contudo, simples; a própria especialização acarreta transtornos de outra ordem: disparidades de

(11) Hıcks, J. R., Introdução ao Estudo da Economia, Livraria Clássica Brasileira, Lisboa, 1956, p. 69.

(12) Guimarães, Nunes, Capital e População, in "Revista Brasileira de Economia", dezcmbro, 1950, p. 22 . 
salários, resultantes dos vários graus de especialização, determinados pelas diferenças de aptidão natural, de treino, de experiência; conforme salienta JACQUELINE JACQUARD. (13) a transferência, duma profissão a outra cria dificuldades de natureza especial

«não basta que o trabalhador esteja disposto a aceitá-las; é prer ciso que possua a aptidão física e intelectual necessárias ao exercício da profissão na qual pensa ingressar».

Por outro lado, aquêles que se especializaram em determinada atividade têm dificuldade em se transplantarem, ràpidamente, para um grupo diferente quando certas circunstâncias ocorrem e determinam a dispensa total ou parcial do trabalho humano.

Essas circunstâncias flutuam com o progresso tecnológico, quando novas invenções, aperfeiçoamentos de máquinas, passam a determinar a dispensa, em certos setores, do trabalho do homem e quando os desejos inconstantes e imprevisiveis do consumidor se voltam para novos produtos.

Finalmente, pode-se avaliar o que representa a não utilização do potencial produtivo de um país pela percentagem da população desempregada; mesmo quando o sistema econômico está funcionando em ritmo acelerado, ainda assim :

«cêrca de 5 a $10 \%$ da população permanece desempregada, como resultado da má distribuição ocupacional.» (14)

EVOLUÇÃO DA POPULAÇÃO BRASILEIRA

Antecedentes Históricos. Os ciclos Econômicos

Segundo Castro Barreto, o fenômeno dos ciclos econômicos continuará a exercer uma "grande influência na propagação da população através do imenso país. (15)

Em que consistiram êsses ciclos que determinaram os movimentos populacionais e as modificações na estrutura da população, a qual, segundo se prevê, continuarão a condicionar.

\section{Para Normano. (16)}

«a característica principal da história da economia brasileira é a permanente mudança das condições dos produtos que poderemos chamar de «produtos reis»: açúcar, cacau, ouro, fumo, borracha, café; cada um dêsses produtos tem o seu lugar na história do país e foram, cada um no seu tempo, o «eixo» da economia nacional (ou estadual) dando ao Brasil uma supremacia mundial temporária.»

(13) JaCquARD, Jacqueline, ob. cit., p. 210.

(14) Colin, Clark, The Conditions of Economic Progress, Macmillan and Co., Limited, 1940, p. 4.

(15) Barreto, Castro, Povoamento e População, Livraria José Olimpio, 1951, p. 92.

(16) Normano, J. F., Evolução Econômica do Brasil, Companhia Editora Nacional, 1937, p. 23. Do original americano Brasil, a study of Economic Types. 
Êsses produtos tiveram o seu «reinado» em épocas diferentes e em áreas diferentes de nossas terras, determinando alguns dêles, os chamados ciclos econômicos, sendo que uns de grande importância político-econômica, como o do açúcar que chegou mesmo a influenciar a causa republicana. (17)

Tendo em vista que êsses ciclos provocaram inicialmente a mobilidade populacional, serão aqui revistos, ràpidamente, ao lado de produtos que, apesar de terem motivado deslocamentos, não chegaram a determinar a formação de ciclos.

\section{Ciclo das madeiras corantes}

O primeiro ciclo econômico foi o da indústria extrativa das madeiras corantes que não foram objeto de consideração por parte de Normano. Dêle nos fala SiMONSEN

«os resultados reais de indústria extrativa da nova terra só poderiam ser colhidos depois da formação de um organismo social próprio com a definitiva ocupação do solo e os benefícios de sua exploração». (18)

\section{Ciclo do Açúcar}

Constituiu o ciclo do açúcar a base econômica da implantação definitiva do europeu no Brasil. Atingiu êsse ciclo o seu apogeu no Século XVII e serviu de pretexto ao rei de Portugal para a obtenção de donatários, com recursos próprios e dispostos a ocupar e explorar tôda a costa brasileira. (19)

Para o estudo da população do ponto de vista econômico, o açúcar tem acentuada importância pois não desempenhou apenas o papel de fixação do europeu no Brasil.

«Foi êle quem gerou os grandes problemas de mão-de-obra cuja solução imprimiu feição característica ao desbravamento das terras brasileiras.» $(20)$

Forçara o colono europeu a cooperação do índio e do negro como elementos indispensávéis.

Para a exploração da indústria açucareira tornou-se necessária a obtenção do braço escravo, à custa de imigrações forçadas que, num periodo de 300 anos, devem ter atingido 3 milhões e meio de sêres humanos. (21)

(17) Diegues Junior, Manoel, A Influência da Economia Agricola na Idéia Republicana, in "Revista Brasileira de Estatistica", Janeiro-Março, 1940, Ano I, n 1.

(18) Simonsen, Roberto C., História Econômica do Brasil, Tomo I, Companhia Editora Nacional, 1937, p. 99.

(19) Recursos Econômicos e Movimentos das Populações, in «Revista Brasileira de Estatistica", Ano I, Abril-Junho, 1940, n² 2, p. 205.

(20) Simonsen, Roberto C., Recursos Econômicos e Movimentos das Populaçóes in «Revista Brasileira de Estatística», Ano I, p. 205.

(21) Simonsen, ob. citada, in «Revista Brasileira de Estatistica». Ano I, p. 205. 


\section{Ciclo da mineração (ouro e diamante)}

Enquuanto os produtos agrícolas - açúcar, cacau, algodão, café, tabaco -- tiveram sua origem e foram cultivados ao longo do litoral, o ouro se localizàva na região centro-oeste do país.

A descoberta do ouro nessa região, no fim do Século XVII, coincidiu com a queda brusca nos preços do açúcar, quando os engenhos atravessavam. grave crise.

A atração do ouro e a depressão econômica das zonas açucareiras determinaram um movimento emigratório das regiões do engenho para a zona de mineração. O ouro provocava o deslocamento da fronteira econômica, ocasionando um desenvolvimento do país e povoando especialmente Minas Gerais. (22)

Assim, se o ouro não serviu à realização de empreendimentos de grandes resultados,

«incentivou uma vultosa imigração para o centro-sul do país, que ocupou definitivamente nossos sertões, permitiu a construção de nossas primeiras cidades no interior; criou um grande mercado de gado e tropas estimulando os paulistas à ocupação e conquista definitiva das regiões do sul; tornou o Rio de Janeiro a capital brasileira e aí criou fortes elementos de progresso; permitiu, finalmente, a concentração e a formação de capitais em escravos e tropas que facilitaram a implantação de café no Vale do Paraíba e nas regiões fluminenses». (23)

A procura do ouro estabilizou a formação do país. (24)

Algodão - Como ocorreu com o açúcar, o algodão, que na época colonial era cultivado na zona norte do país, especialmente na Bahia, Pernambucc e Maranhão, e cuja lavourā continuou acentuada até 1822, declinando em conseqüência da queda dos preços no mercado europeu e com resultado da libertação da escravatura, também determinou um deslocamento da população.

Atualmente, a situação é outra, pois as nascentes indústrias manufatu_ reiras de São Paulo, Minas Gerais e Rio de Janeiro passaram a consumir a parte de algodão que antes se destinava à exportação.

Borracha - A borracha, ouro branco, provocou, cumo o ouro de Minas Gerais, outra corrida, porém na direção do Norte, em semelhança ao deslocamento determinado pelo açúcar e o algodão.

Explorada no país, desde o Século XVI, teve novo surto no comêço do Século XIX, sendo sua verdadeira época áurea, o período 1905-1910.

(22) Normano, ob. citada, p. 39.

(23) Simonsen, ob. citada, p. 49, volume 100 A.

(24) Normano, ob. citada, p. 39. 
A partir de 1910, quando a concorrência da borracha do Oriente ocasionou um retrocesso em nossa exportação, começa seu declínio, propiciando uma retirada na fronteira do Vale Amazônico.

Café - O café que, como a borracha, teve sua origem no Vale do Amazonas e Pará, onde foi introduzido em 1723, veio a se tornar o eixo da economia brasileira.

Atualmente, sua produção ocupa uma grande parte da população dos Estados de Minas Gerais, Rio de Janeiro, Espírito Santo, Paraná, Bahia e Pernambuco, ficando São Paulo com a primazia.

Enquanto o açúcar e o algodão são produzidos quase que para o consumo interno, nas fazendas do sul, quase tudo o que se produz é para a exportação. A lavoura do café tomou grande vulto, determinando o desenvolvimento de uma extensa região que se debatia, há mais de 70 anos, em profunda crise. (25)

Conclui Normano suas observações sôbre os nossos diversos pro dutos: (26)

«a mudança dos principais produtos deslocou a fronteira econômica do país. O ciclo do açúcar formou núcleos agrícolas; o ciclo do ouro perturbou parte dos mesmos e originou novos centros pastoris e agricolas. A borracha, na sua atividade destrutiva, pode ser comparada com o ouro, desde que, em ambos os casos, as corridas iniciais causaram o afastamento de outros ramos de produção. $O$ café combina tôdas essas influências, tendo sido inaugurado como uma «corrida» como a do ouro e da borracha e possuindo ainda o efeito colonizador de outro produto.»

Alteraram-se os eixos econômicos, alterou-se a fronteira. Alterou-se, sucessivamente, a estrutura da população ativa brasileira; ainda hoje reflete esta tôdas essas flutuações do passado.

\section{As Migrações Internas}

Constituem as entradas o primeiro estágio da penetração brasileira. A caça de escravos e a procura de minérios são os pretextos dêste movimento nômade dos sertanejos de gado. (27)

Nossos deslocamentos internos foram, como já vimos, determinados por deslocamentos de eixos econômicos. Também fenômenos de exaustăo têm determinado o enfraquecimento dos recursos econômicos de regiòes, onde muitos colonos haviam se fixado inicialmente. Por uma ou outra razão, è

(25) Simonsen, Roberto C., História Econômica do Brasil, Tomo II, Companhia Editora Nacional, 1937, p. 213.

(26) Normano, ob. cit., p. 74.

(27) Normano, ob. cit., p. 80. 
o Brasil, segundo LinN SMith, o país de maior mobilidade populacional do mundo.

Atualmente, as migrações internas têm sido facilitadas pela relativa miaior facilidade de transportes.

Resumindo, podemos dizer que as principais migrações internas ocorridas no país no periodo de 1700-1940 (28), suas determinantes e os sentidos que tomaram, foram

\section{Determinantes - Épocas - Sentido das migrações}

a) Exploração do ouro e diamantes em Mato Grosso, Goiás e Minas Gerais 1700-60 - Do Nordeste para Minas Gerais. De São Paulo para Minas Gerais. Do Piaui e São Paulo para Mato Grosso e Goiás.

b) Cultura do café no Vale do Paraíba e Norte de São Paulo - 1760-1860 - Do Nordeste e Minas Gerais para as regiões citadas.

c) Exploração da borracha no Amazonas - 1869-1908 - Do Nordeste para o Norte, abrangendo o Território do Acre.

d) a máxima expansão administrativa da capitania paulista - Sec. XVII e XVIII - Para Leste do Estado de São Paulo (Piratininga) para Mato Grosso, Piaui, Norte do Paraná, Santa Catarina e Rio Grande do Sul.

e) Cultura do café em São Paulo - 1850-1940 - Do Nordeste para São Paulo (por terra e mar).

Já em nosso século, as migrações brasileiras estão tendo outro sentido, ocasionadas ainda por condições econômicas. Verificou o Censo de 1940 (29) as seguintes :
De Minas para São Paulo - cêrca de $\ldots . . \ldots \ldots$....
350.000
Do Estado do Rio para o D. F
290.000
Da Bahia para São Paulo
De São Paulo para o Paraná ....................
115.000
De Minas para o
D. F.
110.000

As migrações internas têm concorrido de um lado para melhor distribuição da população no território nacional, de outro para agravar o desequilibrio econômico entre o Norte e o Sul do país. (30)

Mas se a zona Leste continuar também a perder contingentes migratórios, acentua Menezes CôRTes, agravar-se-á o desequilibrio econômico já observado entre a Zona Leste e Sul. (31)

(28) Simonsen, Roberto C., Recursos Econômicos e Movimentos das Populaçóes, in "Revista Brasileira de Estatistica", Ano I, Abril-Junho, 1940, n 2, pp. 206, 207, 204, 210 e 212 .

(29) Migraçôes Internas in "Conjuntura Econômica", Abril, 1952, p. 35.

(30) Idem, idem.

(31) Menezes CôRtes, Ten. Cel. Geraldo, Imigração e Colonização, in "Revista do Serviço Público", Abril, 1954, p. 73. 
Além dessas, há as migrações dos campos para as cidades 1 as migrações rurais-urbanas.

\section{Migrações Rurais-Urbanas}

$\mathrm{Na}$ época colonial, informa-nos Oliveira Viana: (32)

«o gôsto da vida rural decorre então das próprias condições econômicas da colônia. O centrifugismo urbano se torna a fôrça dominante na mecanização dessa sociedade instabilizada».

Mais recentemente, no nosso século, o fenômeno do êxodo rural é universal e se observa também no Brasil.

$\mathrm{Na}$ imigração dó campo para a cidade prevalece o elemento feminino que se desloca à procura de melhores oportunidades de emprêgo, contribuindo assim para elevar a proporção de homens na população rural.

A grande fôrça de atração dos elementos da zona rural para a urbana é o desenvolvimento industrial das grandes cidades, como as perspectivas de melhores salários. As cidades sofrem assim, intensamente, os efeitos das rápidas migrações internas das populações urbanas.

$\mathrm{E}$ como os que se deslocam do meio em que vivem apresentam caracteristicas definidas de idade, relacionadas com o mercado de trabalho, segue-se que

«o fluxo migratório pode alterar com relativa facilidade a estrutura das populações citadinas». (33)

Como já foi dito, as migrações rurais urbanas influenciam grandemente a distribuição da população ativa de um país, uma vez que os que procuram as cidades se dirigem para a indústria; de um lado contribuem elas para aumentar os contingentes industriais dos centros urbanos, de outro para diminuir a população agrícola.

Também o fator natalidade pode alterar uma e outra dessas populações. Assim, nos países agrícolas em que a taxa de natalidade (fertilidade) é geralmente elevada

os dados estatísticos acusam a expansão agricola (onde a população cresceu) em proporções relativamente mais acentuadas. (34)

(32) Oliveira Viana, Evoltução do povo brasileiro, Companhia Editora Nacional, 1938 , p. 95.

(33) "A população do Distrito Federal", através dos censos in Conjuntura Econômica, (março, 1952), pp. 35-36.

(36) Exposição Geral da Situação Econômica do Brasil, in "Revista do Conselho Nacional de Economia", Ano I, (Dezembro, 1952), n 8. 
No Brasil, onde o coeficiente de natalidade é baixo, o deslocamento dos setores rurais para os centros urbanos tem concorrido para aumentar os contingentes citadinos, em detrimento da produção agrícola.

\section{Imigrações}

Há quem não considere os movimentos imigratórios como representativos nos conjuntos nacionais, afirmando-se que

«as grandes massas de população só apresentam alterações, via de regra, como resultados de mudanças de sua própria estrutura, pois os contingentes imigratórios nunca chegam a representar percentagens elevadas nos contingentes nacionais». (35)

Já Pierre Fromont (36) admite a possibilidade dessas alterações:

«quando se antevê a hipótese de um aumento de população, se êste resulta de um excesso de nascimento, a população compreende um grande número de crianças. Se resulta de imigração a população de adultos é maior. (O grifo é nosso).

No que diz respeito ao Brasil, acreditamos que sua estrutura tenha sido modificada pelo menos no início dêste século, pelas correntes imigratórias. Entre 1805 e 1905, recebeu São Paulo o maior afluxo de imigrantes jamais entrado no país - 10.331.630 cidadãos, contribuindo para aumentar a percentagem de adultos e, possivelmente, a de elementos do sexo masculino, da população geral.

Essas correntes imigratórias não encontraram, ao que parece, a mesma continuidade. A pirâmide demográfica brasileira (ver gráfico em anexo), baseada nos dados do censo de 1950 , se afigura típica de uma população crescente, com grande achatamento na base; o número de crianças, menores de 10 anos - é grande, representando uma percentagem de quase $30 \%$ sôbre o total, ou seja, 15.386 .407 para uma população global de 51.944.397.

\section{População Presente de 1920,1940 e de 1950}

A tabela n: 1 nos dá a evolução da população do Brasil, no período de 1920 a 1950, por zonas fisiográficas, e as percentagens de cada uma destas, por ela pode-se inferir os resultados dos deslocamentos internos da população. Os números aparecem em milhares. (ver Tabela $n^{\circ} 1$, em anexo).

As tabelas 2 e 3 nos mostram a população brasileira nos anos de 1940 e 1950, distribuída pelos seguintes grupos de idade: a) menor de 10 anos; b) de 10 a 70 anos; c) de 70 anos em diante.

(35) A População do Distrito Federal através dos Censos, Algumas Características in "Conjuntura Econômica, (março, 1952), p. 35.

(36) Fromont, Pierre, ob. cit. p. 187. 


\section{População Utbana e População Rural em 1950}

Ainda é grande a nossa população rural. Constitui $63,84 \%$ da população global. E' claro que essa percentagem flutua de uma região fisiográfica para outra :

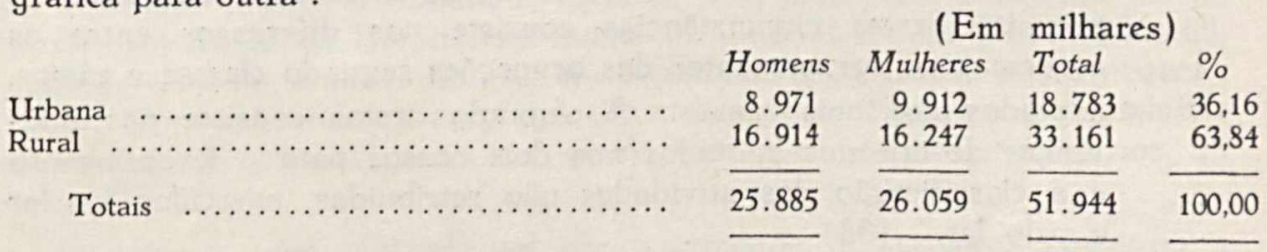

POPULAÇÃo BRASILEIRA. ANÁLISE E INTERPRETAÇÃO. QUADRO DISTRIBUCIONAL

\section{Introdução}

A investigação econômica moderna utiliza método idêntico ao de outras ciências. A economia estuda fatos e procura dispô-los de maneira a ser possivel dêles se tirar conclusões.

Dispor êsses fatos de maneira a que possam responder às nossas indagações, constitui fase conhecida geralmente por Economia Aplicada ou Descritiva que muito se aproxima do estudo de uma ligeira sintese da história econômica brasileira, a fim de que se compreendam as tendências de nossa população. O estudo evolutivo da população ativa brasileira nos últimos 10 anos, ou seja, no período de 1940 a 1950 , datas em que foram realizados os dois últimos censos, permitirá compreender a transição por que estamos passando.

Sendo o fator população o fator determinante do efetivo de mão-deobra de um país, conclui-se que, aumentando a população, o efetivo da mão-de-obra também aumenta. Em paises jovens como o Brasil, porém, êsse aumento pode não determinar o aumento da população ativa de imediato, como veremos mais adiante. Essas observações quanto às possibilidades de nossa população ativa, isto é, o imenso potencial humano de que disporemos num futuro próximo, não afetam a análise que pretendemos fazer da atual estrutura de nossa população ativa.

\section{Dificuldades de Comparação da População Ativa Brasileira}

A estrutura social de um mesmo pais modifica-se com o tempo; as definições e métodos utilizados para a compilação de estatística também sofrem transformações. Disto resulta que as comparações visando a um período longo para um mesmo país, devem, por vêzes, ser objeto de reservas semelhantes às que se aplicam às comparações relativas a sociedades diversas. (37)

As observações acima referem-se a um periodo longo; no entanto, essas mesmas reservas têm que ter o analista ao comparar a população ativa brasi- 
leira de 1940 e 1950. Apesar de se tratar de apenas um decênio, uma certa cautela deve ser tomada, pois como assinala o professor MoRTARA: (38)

"Duas circunstâncias contribuem para criar dificuldades na comparação entre os dados do Censo de 1940 e os de 1950. A primeira destas circunstâncias consiste nas diferenças entre os esquemas de agrupamentos das ocupações segundo classes e ramos, ariotados nos aois censos. A segunda destas consiste nas diferenças de critérios adotados nos dois censos para o levantamento e a classificação das atividades não retribuídas, exercidas no lar e pelo lar." (38)

No Boletim do Censo Demográfico de 1940, havia 10 perguntas relacionadas com a profissão, ofício, emprêgo, cargo ou função principal. Já o de 1950. além das perguntas não serem exatamente as mesmas, acrescentou-se a palavra atividade (atividade exercida como atividade principal). (39)

Segundo ainda o prof. MORTARA, em virtude dessas divergências entre os critérios de caracterização das atividades nos dois censos

"os dados de 1950 provàvelmente descrevem mais fielmente a distribuição dos habitantes segundo a ocupação principal, mas os de 1940 dão a visão mais completa das atividades, mesmo acessórias, especialmente da população feminina." (40)

\section{Principais Conseqüências da Diversidade de Critérios}

Uma das principais conseqüências da disparidade apontada foi que grande número de mulheres distribuídas no censo de 1940 pelos grupos agricultura, silvicultura, indústrias manufatureiras e serviços pessoais, foram no de 1950 englobadas no grupo de atividades domésticas.

Essas desigualdades de critério poderão levar, ainda, o analista a deduções errôneas, se não se fizerem antes as necessárias transições de grupos.

No que diz respeito ao grupo de atividades domésticas a desigualdade reside talvez no fato de que as mulheres ocupadas em atividades domésticas não remuneradas não seriam incluídas no cálculo da população ativa. Êste fato determinou que muitas delas declararam em 1940 uma profissão qualquer apenas para não serem consideradas inativas.

(37) A População Ativa no Mundo, ob. cit., p. 288.

(38) Mortara, Giorgio, As atividades da População da Bahia, segundo os Censos Demográficos de 1940 e 1950 in "Análises Críticas de Resultados dos Censos Demográficos, Estudos de Estatistica Teórica e Aplicada, IBGE, 1956, p. 108.

(39) A População Ativa Feminina e o Recenseamento in "Conjuntura Econômica", (Setembro, 1953), p. 65.

(40) As Atividades da População da Bahia, segundo os Censos Demográficos de 1940 a 1950, ob. cit. p. 109. 


\section{Limites Minimos e Máximos da População Ativa Brasileira}

Resta, porém, saber quando os habitantes de um país começam a formar parte dos efetivos da mão-de-obra. O limite mínimo, isto é, a idade em que a criança começa a trabalhar, varia de pais para pais. Na América do Norte e no Oeste da Europa, no Japão, na Austrália e na Nova Żelândia, a mão-de-obra de menores de 15 anos representa uma fração muito pequena (um por cento no mínimo) da população ativa (41). E' que a idade mínima fixada por lei para término da escolaridade, raramente excede aos 15 anos. (42)

No Brasil, não existindo tal obrigatoriedade, as crianças começam a trabalhar mais cedo e assim sendo, o limite foi estabelecido, pelos diversos censos decenais, em 10 anos, naturalmente por se ter verificado grande número de menores entre 10 e 15 anos trabalhando na lavoura; é interessante assinalar que a participação da criança na vida ativa e maior nos países menos industrializados.

Quanto ao limite máximo de 70 anos estabelecido para nossa população, parece corresponder à nossa estrutura econômico-social.

\section{Crescimento e estrutura da População Ativa Brasileira}

País jovem como é, não acompanhou a população ativa, comparativamente o crescimento da população global; o aumento desta foi em números absolutos, de 10.708.000 no decênio 1940 1950, representando um aumento percentual de $25,9 \%$. As populações globais foram, respectivamente, 41.236 .315 e 51.944 .397 .

A população ativa que, em números absolutos passou de 14.020 milhares a 7.070 , apresentou um decréscimo percentual, caindo de $34,9 \%$ para 32,8\%, em relação às populações totais do país, em 1940 e 1950 .

Contudo, tanto a percentagem de $32,8 \%$ (1950) como a de $34,9 \%$ (1940) são baixas em comparação com a taxa da população ativa do mundo que é de $41 \%$. A população ativa mundial foi estimada em pouco mais de um bilhão em 1950, sôbre uma população total mundial ligeiramente superior a dois bilhões e meio. Naturalmente que há paises em que a taxa é inferior à do Brasil. Essas taxas variam, no mundo inteiro: de $31 \%$ (Ásia do Sudoeste) a 49\% (África tropical e meridional) (43), diferenças que revelam, em parte, a estrutura cultural das sociedades em que se apresentam. Mesmo em relação à América do Sul, cuja taxa média é $38 \%$, nossa taxa ainda é baixa.

Se não houvesse a participação de menores de 15 anos, essa taxa seria provàvelmente mais baixa ainda. O censo de 1950 encontrou, no Brasil, quase 2.000.000 menores de 15 anos trabalhando no setor agropecuário, o

(41) A População Ativa no Mundo, ob. cit., p. 29.5

(42) Idem, Idem. 
que significa uma proporção de $17,3 \%$. E' claro que essa percentagem não é a mesma em tôdas as regiões fisiográficas.

Concorre para a participação do menor na população ativa o fato de não têrmos um ensino primário obrigatório. Em 1950, o Brasil apresentou, para o grupo de idade de 10 a 14 anos, a taxa de $31 \%$ para os meninos e $9 \%$ para as meninas.

A população brasileira acima de 10 anos estava em 1940 e 1950 distribuída pelos diversos grupos de atividade, de acôrdo com a tabela anexa (Tabela $n^{\circ}$ 6). Essa tabela inclui todos os habitantes acima de 10 anos, inclusive aquêles que se encontram em condiçóes inativas, estudantes, pessoas que exercem atividades não remuneradas no lar, discriminando-os por sexos e apresentando a percentagem que cada grupo representa no total. Verifica-se que a percentagem de maiores de 10 anos, ocupados em atividades extradomésticas era, em 1940 , de $48,4 \%$ e de $46,8 \%$, em 1950 , resultados naturalmente prejudicados pela diferença de critério já aludida.

Quanto ao número de mulheres que participavam da população trabalhadora do país representavam estas $15,9 \%$ do total da ativa (Ver Tabela $\left.n^{\circ} 4\right)$.

Em 1950, esta proporção caiu para $14,6 \%$ (Ver Tabela $n^{\circ}$ 5), queda que talvez não expresse coisa alguma pois pode ser uma resultante do fato já ressaltado, de que muitas mulheres não declararam, em 1940, exercer função doméstica não remunerada.

No total da população ativa a percentagem de mulheres na agricultura apresentou a seguinte oscilação. (44)

TOTAL DE MULHERES NA ATIVIDADE AGRICOLA

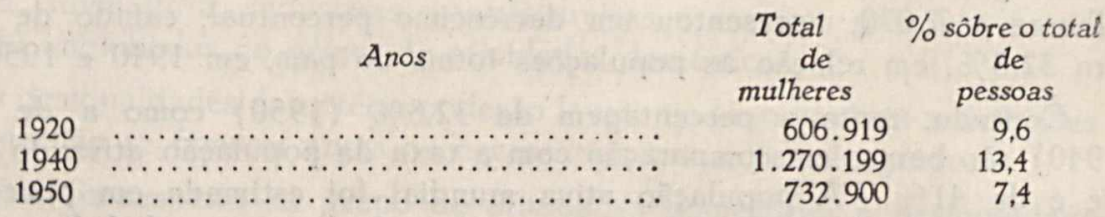

A diferença acentuada entre os censos de 1920 e 1940, não só absoluta como relativa, talvez seja real, podendo explicá-la o grande aumento no número de estabelecimentos agropecuários que de 648.153 , em 1920, passou a 1.904 .589 , em 1940 .

Comparando-se o número de mulheres nos três censos obtêm-se os: seguintes indices: (45)

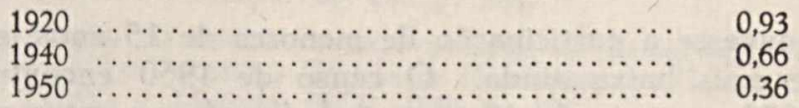

Como se vê, os resultados do censo de 1950 afastam-se dos censos anteriores e as razões devem ser as já apontadas.

(43) A Populą̧ão Ativa no Mundo, ob. ciț, p. 301. 


\section{Comparação dos Grupos de Atividades}

Em virtude da divergência de critérios entre os censos de 1940 e 1950 , algumas transposições se fizeram necessárias a fim de tornar comparáveis seus dados e de se poder analisar as flutuações e aumentos verificados dentro de cada grupo. Essas transposições foram feitas, algumas delas, tendo em vista o conhecimento da própria divergência de critérios entre os dois censos e outras por dedução.

Antes de iniciarmos a comparação entre os grupos, desejamos ressaltar ainda que no caso especial do Brasil - país que, segundo LinN SMITH, tem a maior mobilidade populacional do mundo - o estudo da maior ou menor preferência por certos grupos de atividade torna-se complexo. E' que alguns fatôres são anulados por outros e nunca saberemos ao certo quando o surto de uma determinada atividade atraiu o homem ou quando uma atividade prosperou em função de maior mão-de-obra disponivel.

Em primeiro lugar as mutações profissionais são estimuladas pela extraordinária mobilidade horizontal e facilitada, o que pode parecer estranho, pela ausência de especialização. O nosso operário só agora começa a ser treinado. Nossas Escolas Técnicas não são em número suficiente, encarregando a própria emprêsa privada destas tarefas.

Isto sem falar na dificuldade de comparação entre os censos de 1940 e 1950: segundo êstes. houve um considerável decréscimo no número de mulheres ocupadas em alguns ramos de atividade.

Assim:

"A redução considerável que se verifica no número de mulheres em certas atividades, segundo os censos de 1940 e 1950, tem suscitado da parte de uns, justificadas reservas e de outros, conclusões̀ precipitadas, como por exemplo, o do grande declinio na utilização mão-de-obra feminina." (46)

Assim o grupo agricultura, pecuária e silvicultura apresentou uma queda de 1.270 milhares para 733 milhares. E' que, conforme já foi ressaltado, grande número de mulheres que exerciam uma atividade suplementar, tais como agricultura, bordados, costuras, etc., declararam essas atividades como profissão e assim foram classificadas em 1940 no grupo «agricultura, manu faturas, etc.» em 1950 aparecem elas no grupo «atividades domésticas não remuneradas». É claro que êsse fato viria alterar o grupo atividades domésticas não remuneradas cujo total de mulheres passou de 10.725 a 14.882 , o que representa, evidentemente, um aumento fabuloso, afetando a cifra global que passou de 11.909 a 16.464 milhares, montantes que representam, respectivamente, $41,01 \%$ e $45,03 \%$ da população total dos respectivos anos (ver Tabela $n^{\circ} 6$ ).

(44) A População Ativa no Mundo, ob. cit. p. 301.

(45) Idem, idem.

(46) A População Ativa Feminina e o Recenseamento, ob. cit. p. 64. 
Outras não correspondências de grupos profissionais ocorrem noutros setores. O grupo prestação de serviços, aberto em 1950, não aparece em 1940; dêle constam barbeiros e cabeleireiros, manicuras, pedicuras, lavadeiras, engomadeiras, engraxates, cozinheiras, garções, amas e copeiras. Onde teriam figurado êstes no censo de 1940? o grupo profissões liberais apresentou um decréscimo; de 119 milhares passou a 79 milhares em 1950, sendo a diferença mais evidente, observada no sexo feminino que passou de 40 milhares para 14. E' que constava dêste, em 1940, a administração privada que passou a fazer parte em 1950, provàvelmente dos dois grupos de comércio. $\mathrm{O}$ mesmo deve ter ocorrido com o grupo de atividades sociais que decresceu, passando de 900 milhares para 436 milhares.

Após essas observações de caráter geral. iniciaremos a comparação da população ativa, grupo por grupo (ver Tabela n 7 ).

\section{Agricultura, pecuária e silvicultura}

A fim de tornar comparáveis os resultados dos censos de 1940 e 1950 mod ficou-os o Sr. George Kingston (47), partindo do pressuposto de que a taxa de ocupação da mulher na agricultura, em cada um dos Estados, tenha se modificado naquele decênio, na mesma proporção em que variou a taxa de atividade dos homens.

Assim, se a população feminina agrícola que apresentou uma taxa de decréscimo de quase $43 \%$, contribuindo para fazer cair as taxas gerais nesse grupo de $13,4 \%$ para $7,4 \%$, tivesse aumentado na mesma proporção que a masculina, isto é, se tivesse aumentado de $11,8 \%$, seria ela, em 1950, de 1.420 milhares o que tornaria a população global agrícola nesse ano igual a 10.571 .

Mesmo utilizando-se êsse recurso de raciocinio, verifica-se que foi êsse grupo o que ofereceu menor aumento percentual, nesse periodo, caindo de $67,43 \%$ para $61,92 \%(48)$, enquanto o total de atividades global se manteve quase constante. Esse decréscimo da população agrícola pode dar a impressão de que houve melhor aproveitamento através da mecanização e da racionalizaçâo do trabalho. Contudo, ao que parece, continua o Brasil naquela situação a que se referiu LinN Smith.

Não haverá país no mundo onde a produção - sobretudo a agrícola - resulta de maior soma de esforços e de mais absurdo desperdício de energias.

$E^{\prime}$ interessante assinalar que continua sendo o Brasil um dos paises da América Latina com maior proporção de pessoas ocupadas em atividades

(47) Kingston, George, Alguns aspectos demográficos e econômicos da agricultura no Brasil, in "Revista Brasileira de Estatistica", n 58, Ano XV, (abril-junho, 1954), p. 77.

(48) NOTA - Esse cálculo foi feito levando-se em consideração a hipótese acima; se considerarmos os dados de censo de 1950, a percentagem será de $57,90 \%$ (ver Tabela $\mathrm{n}^{\circ} 7$ ). 
agrícolas, apesar da pressão de mutações de deslocamentos exercida no Nordeste pela exaustão da terra.

Cêrca de $67 \%$ da população ativa e remunerada maior de dez anos se localiza nas regiões rurais vivendo da agricultura (49). Essa população agrícola não se distribui homogêneamente pelo país. A taxa parcial de atividade apresenta uma faixa de variação de $25,09 \%$ a $33,50 \%$ (50) sendo que na zona Norte, a população que nas outras zonas é essencialmente agrícola divide-se entre a agricultura e a indústria extrativa (ver Tabela $\mathrm{n}^{\circ}$ 8), cujas percentagens são respectivamente de $18,99 \%$ e $12,79 \%$.

\section{Induistrias Extrativas}

Como já vimos, a região Norte apresenta uma taxa extremamente elevada de pessoas ocupadas na indústria extrativa. A população das demais $z$ onas varia numa percentagem que vai de 0,54 a 2,87 (ver Tabela $n^{\circ} 8$ ). A taxa mais baixa é dada pela zona Sul, $2,87 \%$.

O número absoluto de ocupados nessa atividade foi, em 1940, de 390 milhares e, em 1950, de 483 milhares; percentagens de 2,79 e 2,88, respectivamente.

As indústrias extrativas são, porém, estacionais e como os dois censos foram realizados em épocas diferentes do ano, pode ter havido discrepâncias nos resultados.

\section{Indùstrias de iransformação}

Também nas indústrias de transformação nota-se um decréscimo da população feminina que pode bem ser resultante da diferença de critério dos dois censos.

Assim, enquanto a população masculina passou de 1.107 milhares a 1.812 , a feminina passou de 293 a 389 milhares, a masculina aumentou na proporção de $66,3 \%$, enquanto a feminina na proporção de $32,7 \%$. Observou-se que o trabalho feminino aumentou mais nos ramos da indústria têxtil (51).

Nesse grupo, a percentagem média da população ativa do pais passou de $9,99 \%$ para $13,06 \%$, o que parece provir do desenvolvimento das indústrias de transformação, no período de 1940 a 1950; o número de pessoas nesse grupo passou de 1.400 milhares a 2.231. Adverte porém o prof. MorTARA (52) que o censo de 1950 teve um âmbito de levantamento mais amplo. o que pode ter influenciado êsses dados.

(49) O IBGE registra apenas como sendo de 33,5\% a população ativa na agricultura.

(50) Essas percentagens foram baseadas nos dados do censo. Não foi feito o acréscimo do aumento proporcional como o foi no cálculo geral da população agricola. Contudo, uma comparação apenas entre grupos e zonas, êsses números servem aos objetivos visados. A percentagem calculada é a taxa parcial de atividade (ver Tabela $\mathrm{n}^{\circ} 7$ ).

(51) Salário na Indústria, in Conjuntura Econômica de Setembro de 1949, Ano III, ñ 9. (Dados tirados do Censo dos Industriários de 1948). 


\section{Comércio (de mercadorias)}

O número de ocupados nos ramos de comércio de mercadorias passou de 749 milhares a 958 milhares, aumentando a sua percentagem de 5,34\% para $5,61 \%$. O número de hømens passou de 698 a 869 milhares e o de mulheres de 51 a 89 milhares.

\section{Comércio (de imóveis e valores imobiliários, créditos, seguros e capitalização)}

Êste grupo, embora represente uma taxa pequena de população global, teve um aumento percentual grande. A população passou de 52 milhares a 116 milhares; a taxa passou de 0,36 a 0,67 . O maior aumento percentual verificou-se na população feminina, pois foi de $77 \%$.

\section{Prestação de Serviço}

Esclarece o prof. Mortara que o Serviço Nacional do Recenseamento de 1950 reagrupou os dados de 1940. Contudo, desconhecemos êsses reagrupamentos. Conforme já declaramos, não aparece, no censo de 1940 , o grupo prestação de serviços, de modo que não tentaremos neste nenhuma comparação por ser difícil observar as causas de suas variações. Em 1950, a população total classifica nesse grupo foi de 1.673 milhares, sendo 926 milhares de mulheres e 747 milhares de homens.

\section{Transporte, Comunicações e Armazenagem}

Em primeiro lugar, queremos esclarecer que o esquema de agrupamento de 1940, não inclus a palavra Armazenagem. Naturalmente o esquema do censo de 1950 quis tornar mais claro êsse grupo de atividades, pressupondo-se, pois que a armazenagem seria abrangida pelo grupo de 1940. O número de mulheres, com uma taxa de aumento de $107 \%$, fêz, pràticamente, dobrar a população feminina dêsse grupo no periodo de 1940 a 1950 . O aumento percentual dos homens foi inferior; a percentagem de aumento foi de $45,2 \%$.

A percentagem dentro da população ativa do pais passou de $3,39 \%$ a $4,08 \%$. Êsse aumento, embora ligeiro, pode ser ocasionado peì maior investimento em rodovias. A partir de 1946 passaram a ser empregados recursos em estradas de rodagem com muito mais intensidade.

Ao que parece êsse grupo não mereceu as preferências das mulheres que no censo de 1940 declararam uma profissão qualquer para não serem julgadas inativas. O grupo não se prestava para uma "fuga" daquelas que "precisavam declarar uma atividade extradoméstica qualquer. Assim sendo, o aumento da população feminina nesse setor, parece ser real.

(52) As atividades da População da Bahia Segundo os Censos Demográficos de 1940 a 1950, ob. cit. p. 111 . 
E' bem verdade que êsse aumento em números absolutos não é grande; passou de 14 milhares a 29 milhares enquanto que a masculina, bem superior, passou de 460 a 668 milhares.

\section{Profissões Liberais}

A população absoluta recenseada nesse grupo foi de 119 milhares em 1940 e 79 milhares em 1950. A taxa dentro da população ativa global caiu de $0,85 \%$ para $0,46 \%$, o que não parece corresponder à realidade. A população absoluta feminina nesse ramo passou de 40 milhares para 14 , revelando uma queda de $65 \%$; a masculina cuja população absoluta foi respectivamente de 119 e 65 milhares, nos anos de 1940 e 1950, apresentou um decréscimo de $21,5 \%$.

A comparação neste grupo é tremendamente dificultada pela diversidade de um esquema e outro nos dois censos. O censo de 1940 inclui neste grupo, ensino particular, culto e administração privada. (!) Evidentemente que tendo sido desdobrado o grupo, ficando apenas com as profissões liberais teria êle que apresentar diminuição. Contudo, como vimos, os decréscimos não são proporcionais para os dois sexos.

\section{Atividades Sociais}

Ainda a comparação é prejudicada pelas diferenças de critérios de levantamento e classificação. As classes de atividades de previdência social e de assistência médico-hospitalar pública que no censo de 1940 foram incluídas em administração pública, etc. aparecem em 1950 no ramo das atividades sociais. (53) Ainda assim o número de ocupados nesse grupo passou de 900 milhares a 435 milhares, diminuindo percentualmente de $6,42 \%$ para $2,55 \%$.

A população masculina que era de 438 milhares em 1940 - número quase igual ao total geral dêsse grupo em 1950, passou para 201 milhares e a população feminina de 438 para 234 milhares.

\section{Administeração Pública - Legislativo e Justiça}

Como já frisamos, êsse grupo será afetado pela diversidade de critérios. Em números absolutos os ocupados em administração pública, Legislativo e Justiça passou de 311 milhares a 261 milhares, provocando uma queda percentual de 2,21 para $1,52 \%$.

A população feminina que era em 1940 de 84 milhares passou a ser quase a metade ou seja 40 milhares. A masculina não apresentou quase alteração: 227 milhares em 1940 e 221 milhares em 1950.

Apesar da exclusão apontada, a proporção de homens aumentou consideràvelmente, a taxa de percentagem passou de $0,6 \%$ para $1,6 \%$.

(53) Mortara, Giorgio, As atividades da população da Bahia, segundo os censos démográficos de 1940 a 1950 , ob. cit., p. 112. 


\section{Defesa Nacional e Segutrança Pública}

O número de ocupados em segurança pública, 172 milhares em 1940 e 251 milhares em 1950, modificou a taxa percentual de $0,59 \%$ para $0,69 \%$.

\section{CONCLUSÕES}

Tentaremos uma sintese, num comentário geral, do significado da estrutura de nossa populacão ativa, procurando tanto quanto possivel investigar até que ponto os movimentos populacionais contribuiram para lhe dar a feição atual e até que ponto o desenvolvimento econômico foi determinando a disposição de seus componentes ativos.

Inicialmente é necessário que se digam algumas palavras sôbre o grupo das atividades domésticas, de difícil interpretação, pois como afirma Colin (54)

"A alta percentagem de empregados domésticos na população encontra-se em três paises de estrutura diversa, como a Índia, a Noruega e a Grã-Bretanha.» ( $\mathrm{O}$ grifo é nosso)

Passemos às atividades agricolas. Continuam a predominar, no Brasil, as atividades agrícolas, apesar do decréscimo de $5,52 \%$ ocorrido na sua percentagem.

Tendo sobrevindo o decréscimo e tendo aumentado nossa população no decênio de 1940-1950 era fatal que os índices da produção agricola se tornassem inferiores aos do aumento da população.

Assim, em 1950 veio a caber a cada habitante uma quantidade menor de produto agricola. VAN Der Meiren (55) concluiu que existem duas causas básicas «para a lenta resposta da oferta ao aumento da procura:

“a) as migrações dos trabalhadores agricolas para as cidades e centros industriais e a

b) insuficiência dos investimentos na agricultura".

A primeira destas causas já foi aqui analisada. Quanto aos investimentos, segundo nos informa Conjuntura Econômica, apesar de ter sido duas vêzes maior que o valor da produção expressa em cruzeiros - de 1940 - os financiamentos feitos pelo Banco do Brasil,

"essa evolução pouco representa pois é sabido que é bastante pequeno o financiamento rural em relação à produção». (56)

A Carteira Agricola daquela instituição de crédito não dispõe de recursos. Assim, para um número de estabelecimentos de 2.2 milhões a Carteira só pôde atender a 19.250 ou seja menos de $1 \%$.

(54) Clark Colin, ob. cit. p. 184.

(55) Van Der Msiren, Pierre, Aspectos do Desenvolvimento Econômico do Brasii. Estudos de Economia Teórica e Aplicada, n 5, julho de 1953 - Escola de Sociologia e Política de São Paulo.

(56) "Conjuntura Econômica", Ano V, n 10, outubro, 1951, p. 7. 
Como vimos, apesar de ser grande o número de nossa população ativa ocupada na agricultura - atualmente $64,76 \%$ - superior mesmo ao que seria desejado, pois a diminuição dessa taxa é sinal de desenvolvimento econômico, a produção nesse ram $=$ é baixa: isto decorre do fato de nossa agricultura não ser mecanizada. Não dispomos de equipamento suficiente que permita a transmissão de maior número de braços para a indústria.

E' bem verdade que esta, como o atrativo de altos salários e a perspectiva de vida de maior conforto nas cidades tem atraido grande contingente da população agrícola. Se a lavoura não se modernizar, adotando além disso processos racionalizadores, se ressentirá ainda mais.

As transformações tecnológicas provocam mudanças sociais e ocupacionais de grande vulto conduzindo a uma gradativa eliminação do trabalho manual e determinando o rápido crescimento do número dos trabalhadores de escritórios e operários especializados.

$\mathrm{O}$ indice das indústrias extrativas baixou, o que demonstra um bom indício, pois

«de um modo geral, não é possível a um grande país, com elevada população obter alto rendimento nacional, mediante a exploração das indústrias extrativas e de cultivo da terra». (57)

Nas indústrias de transformação a taxa de ocupados aumentou razoàvelmente, embora continue ainda baixa. Como sabemos, as indústrias de transformação se encarregam não só da produção do capital fixo como da sua substituição.

A produção industrial que se destina às indústrias de transformação foi assim discriminada pelo IBGE: (58) evtrativa, mineral, cimento, vidro e cerâmica, siderurgia, papel e borracha e as que se destinam a manufatura dos bens de consumo em: produtos farmacêuticos, calçados, produtos alimentares, bebidas, fumo, construção civil e energia elétrica.

Para dar uma melhor visão das percentagens dos grandes grupos de atividades (Ver Tabela $n^{\circ}$ 9), adotaremos a divisão feita por Colin ClARK (59) das atividades produtoras

Atividades primárias: agricultura, pecuária e silvicultura e indústrias extrativas;

Atividades secundárias: indústrias de transformação (cobrindo indústrias manufatureiras, construção de edifícios e obras públicas) e indústrias extrativas minarais: (60)

(57) Simonsen, Roberto, Alguns Aspectos da Politica Econômica mais conveniente ao Brasil, no periodo de após guerra, p. 7.

(58) "Anuário Estatistico", I.B.G.E., 1956, p. 163.

(59) Ob. cit. p. 182.

(60) Observa Clark Colin que, em alguns paises a indústria extrativa mineral é considerada atividade primária baseando-se no fato de que constituem exploração de recursos naturais. $\mathrm{N}$ atabela que organizamos, ela aparece como atividade primária. 
Atividades terciárias: serviços (comércio e distribuição, transporte, administração pública, serviços pessoais e profissionais. (Ver Tabela $n^{\circ}$ 9), elaborada em obediência à classificação acima) .

No Brasil, a percentagem das atividades secundárias segundo o censo de 1950 é de $13,07 \%$, sendo a taxa de participação nesse mesmo ano, de apenas $6,10 \%$ (ver Tabela $n^{\circ} 9$ ), o que se deve ao fato de ser a percentagem das pessoas acima de 10 anos que fazem parte da população ativa, de apenas $46,8 \%$.

O aumento percentual de $4,82 \%$ para $6,10 \%$, de 1940 a 1950 , deve-se em parte aos reflexos da guerra, quando fomos obrigados a substituir por nacionais parte dos produtos manufaturados importados. Terminada a guerra, restabelecida a importação de bens de equipamento, a produção indusetrial continuou em ritmo ascendente.

Um dos componentes mais importantes das atividades secundárias é a indústria metalúrgica. Considera-se como característica dos países industrializados a participação de $10 \%$ de sua população ativa neste grupo.

$O$ indice de produção de nossa indústria metalúrgica passou de 127 (ano base 1939) a 549 em 1950. (61) As produções de ferro gusa, aço e laminados tiveram um aumento considerável, passando, respectivamente, de 185.570 a 728.979 , de 141.201 a 768.557 e de 135.293 a 623.258 toneladas no decênio 1940-1950. (62)

Apesar dêsse aumento, as indústrias metalúrgicas ocuparam o quarto lugar dentro das indústrias de transformação, sendo que as duas colocadas nos primeiros lugares: produtos alimentares, bebidas e fumo e fiação e tecelagem, têm uma percentagem bem expressiva, mas são indústrias que se ocupam dos bens de consumo.

Podemos assinalar um aumento significante no setor que se destina a produção de capital fixo - o cimento. A produção de cimento Portland quase dobrou de 1940 para 1950. (63)

Se compararmos os índices dos volumes físicos da produção da agricultura e da indústria, veremos que o índice da agricultura em 1950 é de 129 e o da indústria é de 230 (ano-base 1939). (64)

Esses indices mostram que caminhamos para um equilibrio econômico mas de difícil obtenção, como assinala Clark Colin:

"A transferência da população ativa, da produção primária para a secundária e a terciária, continua a ocorrer e talvez continue por muitos séculos mais. Isto prova que ainda não se conseguiu - equilibrio econômico mundial e que, na verdade, o mundo está muito longe de obtê-lo".

(61) Fonte: "Revista Brasileira de Economia", (Março, 1953).

(62) "Anuário Estatistico do Brasil", IBGE, 1956, p. 135.

(64) Van Der Meiren, Pierre, Aspectos do Desenvolvimento Econômico do Brasil, ob. cit. p. 10. 


\section{PIRÂMIDE DEMOGRÁFICA do BRASIL}

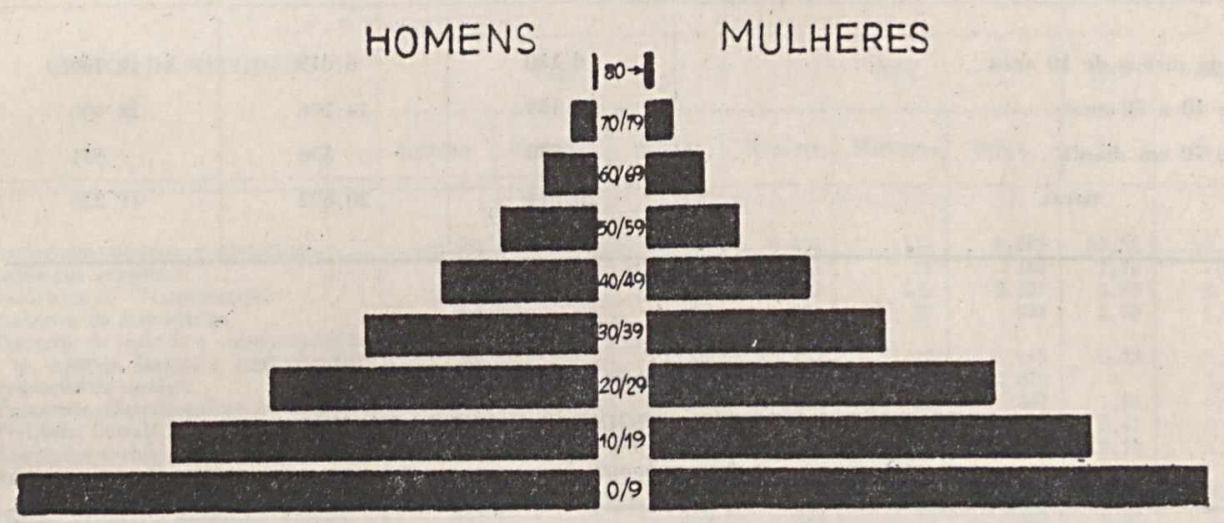

Tabela $n: 1$

POPULAÇÃO BRASILEIRA *

Especificação por zonas fisiográficas da Federação

Anos de 1920, 1940 e 1950

\begin{tabular}{|c|c|c|c|}
\hline ZONAS FISIOGRÁFICAS & 1920 & 1940 & 1950 \\
\hline \multirow{2}{*}{ 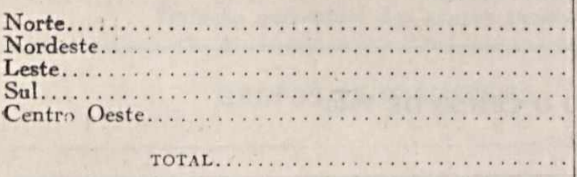 } & $\begin{array}{r}1.439 \\
7.434 \\
12.875 \\
8.129 \\
758\end{array}$ & $\begin{array}{r}1.462 \\
9.974 \\
15.626 \\
12.916 \\
1.258\end{array}$ & $\begin{array}{r}1.845 \\
12.494 \\
18.903 \\
16.997 \\
1.737\end{array}$ \\
\hline & 30.636 & 41.236 & 51.976 \\
\hline
\end{tabular}

$\%$ SOBRE O TOTAL

\begin{tabular}{|c|c|c|c|}
\hline ZONAS FISIOGRÁFICAS & $\begin{array}{c}1920 \\
\%\end{array}$ & $\begin{array}{c}1940 \\
\%\end{array}$ & $\begin{array}{c}1950 \\
\%\end{array}$ \\
\hline \multirow{2}{*}{ 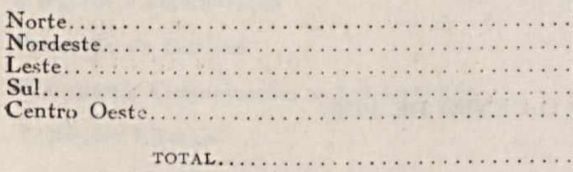 } & $\begin{array}{r}4,01 \\
24,68 \\
45,60 \\
23,55 \\
2,16\end{array}$ & $\begin{array}{r}3,65 \\
24,19 \\
37,89 \\
31,32 \\
3,05\end{array}$ & $\begin{array}{r}3,58 \\
24,03 \\
36,40 \\
32,64 \\
3,35\end{array}$ \\
\hline & 100,00 & 100,00 & 100,00 \\
\hline
\end{tabular}

* Dados extraídos da Exposição Geral da Situanão Econômica do Brasil in Revista do Conselho Nacional de Economia - Out. Nov. 1952 - Ano II - n。 67, p. 57

Nota - Os dados referentes a 1950 foram retirados diretamente do Anuário Estatistico do Brasil, 1956 - total geral difere um pouco de outros que figuram no Anuário por incluir populações de alguns Municípios cujo material foi extraviado. O total que aparece noutras tabelas é de 51.944 milhares. 
TABELA NO 2

POPULAÇ̃̃O DO BRASIL, SEGUNDO O CENSO DE 1940

(em milhare.r)

\begin{tabular}{|c|c|c|c|}
\hline GRUPOS DE IDADE & HOMENS & MULHERES & TOTAC. \\
\hline Com menos de 10 anos. & 6.180 & 6.019 & 12.199 \\
\hline De 10 a 70 anos..... & 14.159 & 14.276 & 28.406 \\
\hline De 70 em diante......... & 275 & 356 & 631 \\
\hline TOTAL. & 20.614 & 20.622 & 41.236 \\
\hline
\end{tabular}

TABELA No. 3

POPULAÇÃO DO BRASIL, SEGUNDJ O CENSO DE 1950

(em milhares)

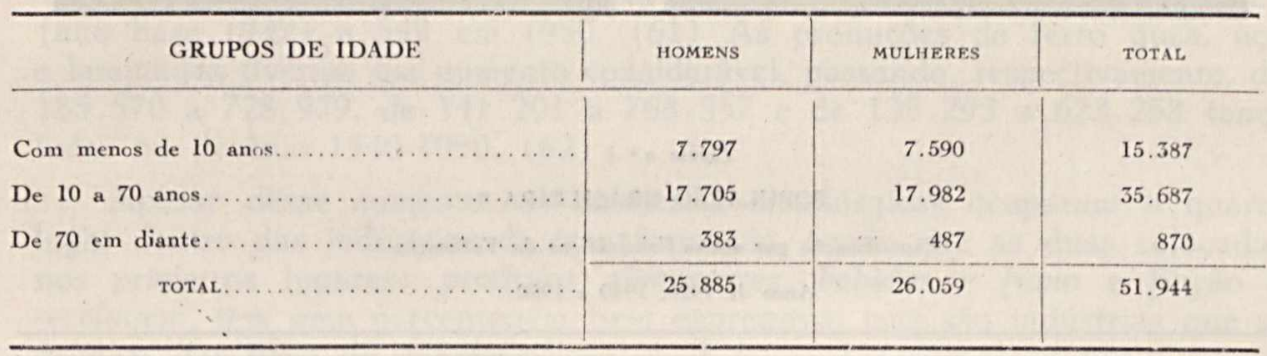

TABELA NO 4

POPULAÇÃO ATIVA, SEGUNDO O CENSO DE 1940

(em milhares)

\begin{tabular}{c|c|c|c|c|c|c|c|}
\hline TOTAL & HOMENS & MULHERES & $\begin{array}{c}\text { DE } \\
\text { HOMENS }\end{array}$ \\
\hline 14.020 & 11.780 & 2.240 & 84,10 & 15,9 \\
\hline
\end{tabular}

TABELA No. 5

POPULAČ̃̃o ATIYA, SEGUNDO O CENSO DE 1950

(em milhares)

\begin{tabular}{c|c|c|c|c}
\hline TOTAL & HOMENS & MULHERES & $\begin{array}{c}\% \text { DE } \\
\text { HOMENS }\end{array}$ & $\begin{array}{c}\% \text { DE } \\
\text { MULHERES }\end{array}$ \\
\hline 17.070 & 14.572 & 2.498 & 85,4 & 14,6, \\
\hline
\end{tabular}


DISTRIBUIC̃̃O DOS HABITANTES DE 10 ANOS E MAIS, SEGUNDO OS GRUPOS

TABELA N. ${ }^{\circ} 6$

DE ATIVIDADE PRINCIPAL E O SEXO

(Nímeros relativos e absolutos) - Censo de 1940 e 1950

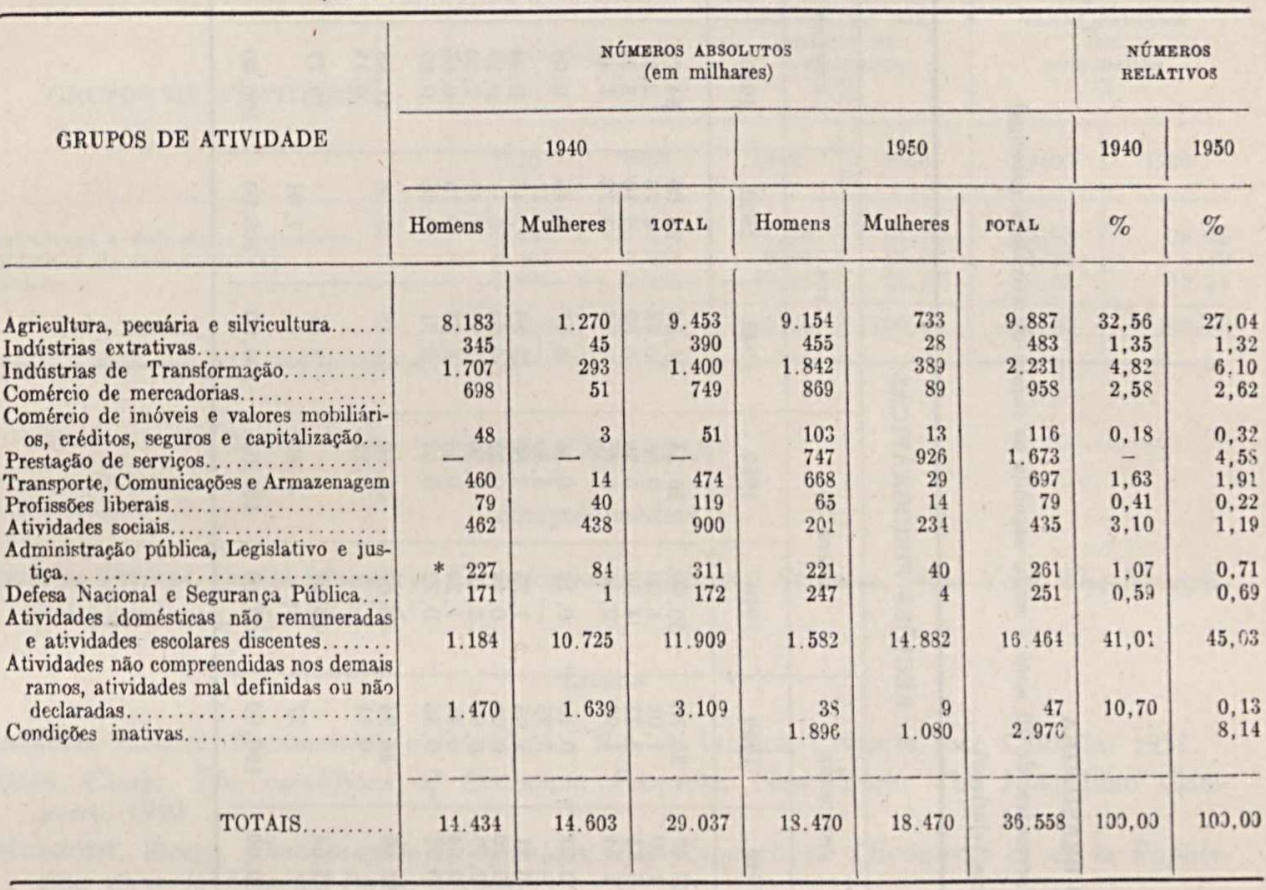

*) Inclusive as classes previdència social e assistènciz h̀ospitalar-pública.

POPULAÇÃO ATIVA BRASILEIRA

TABELA n-0 7

Variação percentual dos grupos profissionais, de acôrdo com os censos de 1940 e 1950

\section{GRUPOS PROFISSIONAIS}

Agricultura, pecuária e silvicultura $\ldots \ldots \ldots \ldots \ldots \ldots \ldots$

Indústrias extrativas. .

Indústrias de transformação.

Comércio de mercadorias.

Comércio de imóveis e valores mobiliários, créditos,

e seguros e capitalização . . . . . . . . . . . . . . . . . . .

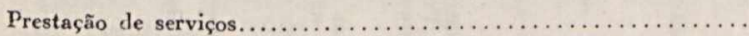

Transporte, Comunicações e Armazenagem ................

Profissões Liberais . . . . . . . . . . . . . . . . . . . . .

Atividades Sociais.

Administração Pública, Legislativo e Justiça

Defesa Nacional e Segurança Pública.

TOTAL.

\begin{tabular}{|c|r|}
\hline $\begin{array}{c}1940 \\
\%\end{array}$ & $\begin{array}{c}1950 \\
\%\end{array}$ \\
\hline 67,43 & 57,90 \\
2,79 & 2,88 \\
9,99 & 13,06 \\
5,34 & 5,61 \\
0,36 & 0,67 \\
& 9,80 \\
3,39 & 4,08 \\
0,85 & 0,46 \\
6,42 & 2,55 \\
2,21 & 1,52 \\
1,22 & 1,47 \\
\hline 100,00 & 100,00 \\
\hline
\end{tabular}




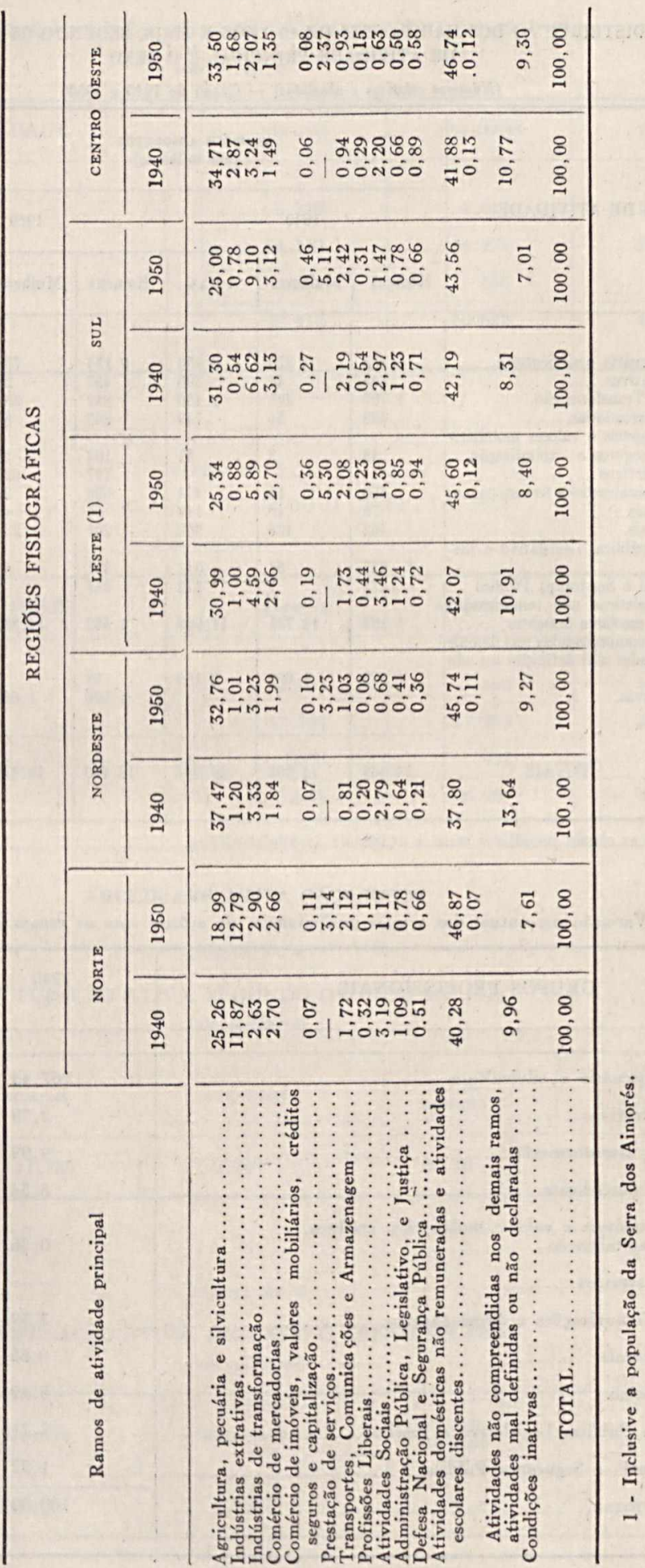


TABELA No. 9

DISTRIBUIÇÃO DA POPULAÇÃO ATIVA BRASILEIRA

\begin{tabular}{|c|c|c|c|c|c|c|}
\hline \multirow[t]{2}{*}{ GRUPOS DE ATIVIDADES } & \multicolumn{2}{|c|}{ POPULAÇ̃̃o ATIVA } & \multicolumn{2}{|c|}{$\begin{array}{l}\text { PROPORÇÃO POR } \\
\text { GRUPOS DE } \\
\text { ATIVIDADES } \\
\%\end{array}$} & \multicolumn{2}{|c|}{$\begin{array}{c}\text { TAXAS PARCIAIS } \\
\text { DE } \\
\text { ATIVIDADES } \\
\%\end{array}$} \\
\hline & 1940 & 1950 & 1940 & 1950 & 1940 . & 1950 \\
\hline 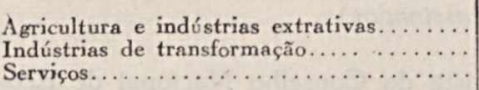 & $\begin{array}{l}9.845 \\
1.400 \\
2.775\end{array}$ & $\begin{array}{r}11.054 \\
2.231 \\
3.785\end{array}$ & $\begin{array}{r}70,20 \\
9,99 \\
19,81\end{array}$ & $\begin{array}{l}64,76 \\
13,07 \\
22,17\end{array}$ & $\begin{array}{r}33,91 \\
4,82 \\
9,67\end{array}$ & $\begin{array}{r}28,36 \\
6,10 \\
12,34\end{array}$ \\
\hline TоTAL.. & 14.020 & 17.070 & 100,00 & 100,00 & 100,00 & 100,00 \\
\hline
\end{tabular}

\section{BIBLIOGRAFIA}

\section{Encyclopaedias}

SORokin PrTIRIM, Social Momility, Encyclopaedia of Social Sciences, New York The Macmillan Company, MCMXXXV.

\section{Livros}

Barreto, Castro. Povoamento e População, Rio de Janeiro, Livraria José Olimpio, 1951.

Colin, Clark. The conditions of Economic Progress, New York, The Macmillan Company, 1940.

Fronmont, Pierre. Demographie Economique, Les Rapports de l'Economie et de la Population dans le Monde, Paris, Payot.

Hicks, J. R. Introdução ao Estudo da Economia, Lisboa, Livraria Clássica Editora, 1956. JaCCARD, Madeleine. La Mobilitẻ de la Main d'oeuvre et les problèmes du chômage et de la penurie de travailleurs, Lausanne, F. Rouge E cie s.a., Librairie de l'Université, 1944.

LANDry, Adolphe. Traité de Demographie. Paris, Payot.

Normano, J. F. Evolução Econômica do Brasil, São Paulo Companhia Editora Nacional, 1938.

Oliveira Viana. Evolução do Povo Brasileiro, São Paulo, Companhia Editora Nacional, 1938.

Simonsen, Roberto, C. História Econômica do Brasil, 1500 - 1820, São Paulo, Companhia Editora Nacional, Tomo I, 1937.

\section{Panfletos e Publicações Oficiais}

Anuário Estatistico do Brasil, I.B.G.E.

Mortara, Giórgio. As atividades da População da Bahia segundo os Censos Demográticos, Estudos de Estatística Teórica e Aplicada, Rio de Janeiro, I.B.G.E. Conselho Nacional de Estatistica, 1956.

Simonsen, Roberto C. "Alguns Aspectos da Politica Econômica mais Conveniente ao Brasil no periodo de após guerra".

Van Der Merren, Pierre. Apóstos do Desenvolvimento Econômico do Brasil, Estudos de Economia Teórica e Aplicada, São Paulo, Escola de Sociologia e Politica, n. 5 , julho.

\section{Revistas Técnicas (artigos assinados)}

Diegues Junior, Manoel. A influência da Economia Agricola na Idéia Republicana, "Revista Brasileira de Estatistica", Ano I, n. ${ }^{\circ}$ 2, (abril - junho, 1940). 
Guimarães, Nunes. Capital e População "Revista Brasileira de Economia", Ano IV, n. ${ }^{\circ}$, (dezembro, 1950).

Kingston, Jorge. Alguns Aspectos Demográficos e Econômicos da Agricultura no Brasil. "Revista Brasileira de Estatistica", Ano XV, n.0 58, (abril - junho, 1954).

Menezes CôRtes, Geraldo. Imigração e Colonização, "Revista do Serviço Público", Ano XVII, n. $0^{\circ}$, (abril, 1954).

Simonsen, Roberto C. Recursos Econômicos e Movimento das Populações, "Revista Brasileira de Estatistica", Ano I, n. ${ }^{\circ} 2$ (abril - junho, 1940).

\section{Revistas Técnicas (artigos não assinados)}

Exposição Geral da Situação Econômica do Brasil, "Revista do Conselho Nacional de Economia", Ano I, (dezembro, 1952).

A população ativa no mundo, "Revista Brasileira de Estatistica", Ano III, n. ${ }^{\circ}$ 68, (outubro - dezembro, 1956).

A população do Distrito Federal através dos Censos, Algumas Características, "Conjuntura Econômica", Ano VI, n.* 3, (março, 1952).

A população feminina e a Recenseamento, "Conjuntura Econômica", Ano VII, n. ${ }^{\circ}$ 9, (setembro, 1953) .

Migrações Internas, "Conjuntura Econômica", Ano VI, n. ${ }^{\circ} 4$, (abril, 1952).

Recursos Econômicos e Movimento das Populações, "Revista Brasileira de Estatistica", Ano I, n. ${ }^{\circ}$ 2, (abril - junho, 1940).

Salátio na Indústria, "Conjuntura Econômica", Ano III, n. ${ }^{\circ} 9$, (setembro, 1949). 